\title{
The Gynecological Disorders in Dairy Cattle on the Survey of Allahabad
}

\author{
Ngangkham James Singh ${ }^{1}$, Ajit Singh ${ }^{2}$ \\ Department of Animal Husbandry, Government Veterinary Hospital Chilla Allahabad, India
}

\begin{abstract}
The genetic selection has resulted in gynecological disorder dairy cow with very high milk yields but reduced fertility, due mainly to an increase in gynecological disorders. The research was conducted to estimate the proportion of gynecological disorders among dairy cattle. The factors estimated were; cow parity and gynecological status. The result of this experiment showed the incidence of gynecological disorders in high yielding dairy cows was prevalent. Repeat breeding was the major postpartum reproductive problem comprising (37.44\%) of the samples. Higher gynecological disorders were also associated with lower parity. These disorders subsequently reduced reproductive performance by prolonged intervals from calving to first artificial insemination and from calving to pregnancy. Abnormalities in the gynecological system such as repeat breeder, silent heat, anestrous and ovarian cysts, as well as lower fertility have been recorded during the lactation. In conclusion, the study revealed that incidence of repeat breeder is mostly prevalent in dairy cows. Moreover, the incidence of gynecological disorders was higher in summer season and hence appropriate preventive and or therapeutic measures as per the type of abnormalities need to be undertaken.
\end{abstract}

Keywords: Gynecology, Cattle, Anoestrus, Repeat breeder and Reproduction.

\section{Introduction}

Reproductive performance is one of the important factors determinating the profitability of the dairy farmers. This can be achieved by resuming the ovarian cycle within 30 days of postpartum, first service conception is less than 90 days, with an average caving interval of one year. Fat, one of the nutrients apparently enhanced postpartum reproductive performance by increasing the energy status of the animals and thus stimulated the ovarian follicular growth and luteal functions (Highshoe et al., 1991; Wehrman et al., 1991). Increased milk production has been the emphasis of genetic improvement programs. However, decreasing reproductive performance was observed coincident with increasing lactational yields (Butler and Smith, 1989; Butler, 2000; Barrett, 2000; Lucy, 2001). Substantial energy requirements at the onset of lactation in high yielding dairy cows result in a severe negative energy balance during the early lactation period (Bell, 1995), which may adversely impact postpartum health and fertility (de Vries et al., 1999; Lucy et al., 1991). This research reports the incidence of various gynecological disorders and its effect on milk production in dairy cows in Allahabad.

\section{Materials and Methods}

The research on gynecological parameters and abnormalities of dairy cows was undertaken from February to September 2013 in Block Jasra Allahabad. Individual cows or records included in the study were obtained either by interview and/or from individual record sheets. Data were used to calculate gynecological disorders for the last calving and their effect on gynecological performance Records on insemination, conception, and calving of dairy cows were used to determine the following basic reproduction parameters: days between parturition and first service; and days open (days between parturition and conception). The various types of reproductive disorders were grouped into 4 categories: 1) Ovarian cysts which are fluid-filled structures $\geq 20 \sim 25 \mathrm{~mm}$ in diameter that persist in the absence of a corpus luteum (CL) for more than 20 days (Roberts, 1971; Kesler and Garverick, 1982; Garverick, 1997; Wiltbank et al., 2002); 2) Anestrus, which is defined as the lack or absence of the expression of estrus; 3) Repeat breeder which is defined as the cow that has clinically normal reproductive track with normal or nearly normal oestrous cycles and oestrus periods and has been bred two or more times to a fertile bull but failed to conceive (Roberts, 1971); and 4) Silent heat, defined as a cow that has a normal reproductive cycle and ovulation takes place but there are no heat signs. However, the cow is often blamed for the shortcomings of the herdsman who does not notice the (week) heat signs (Gietema, 2005). Data was subjected to the Generalized Linear Model procedure (PROC-GLM) of the Statistical Analysis System (SAS Institute, Cary, NC, USA). Differences among treatment means were determined using Duncan's multiple range tests. Statistical significance was established at $p<0.05$.

\section{Results and Discussion}

The survey of gynecological disorder findings are summarized in Table 1 . Repeat breeder had the highest incidence (37.44\%); followed by anestrous (26.67\%); silent heat $(23.58 \%)$; and ovarian cysts $(12.31 \%)$. In table 2 the effect of parity distribution on Gynecological disorders. Cows in the $2^{\text {nd }}$ parity had the highest number of disorders. Cows with parities of 1,2 and 3 have more gynecological disorders than those with a parity of 4, 5, 6 and higher. Causes of reproductive failure are categorized into repeat breeding, silent heat, anestrus and ovarian cysts. The result of this study concurs with the findings of earlier researches on the effects of increased lactation on reproductive efficiency of dairy cows. Repeat breeders had the highest incidence of reproductive disorders. Repeat breeding can be a major factor involved in infertility. These cows are characterized by low fertilization rates (Graden et al., 1968) and early embryonic loss (Gustafsson and Larsson, 1985), thereby decreasing overall conception rates (Ferreira et al., 2010; Yusuf et al., 2010). 


\section{International Journal of Science and Research (IJSR) \\ ISSN (Online): 2319-7064}

Index Copernicus Value (2013): 6.14 | Impact Factor (2014): 5.611

Table 1: Incidence of repeat breeder, silent heat, Anoestrus and ovarian cyst in dairy cow of jasra block Allahabad.

\begin{tabular}{|c|c|c|}
\hline Problem & No. of cases & Percent of cases (\%) \\
\hline Repeat breeder & 73 & 37.44 \\
\hline Silent heat & 46 & 23.58 \\
\hline Anoestrus & 52 & 26.67 \\
\hline Ovarian cyst & 24 & 12.31 \\
\hline Total & 195 & 100 \\
\hline
\end{tabular}

Potential causes of repeat breeding include sub-clinical infection of reproductive tract (Rao, 1982), age of the animal (Barlett et al., 1986), errors in detection of oestrus (DeKriuf, 1978), endocrine dysfunction (Gustafsson et al., 1986), nutritional deficiencies and others (Francos et al., 1977). Silent heat is regarded as one of the most prominent infertility problems in dairy farms, affecting about $40 \sim 60 \%$ of post-partum periods (Claus et al., 1983; Schopper et al., 1993). The high rate of silent heat is mainly a result of bad oestrus detection (Mwaanga and Janowski, 2000; Opsomer and Kruif, 1999). According to some authors, the elevated progesterone levels during oestrus and inhibition of oestrus behavior result to negative energy balance in high yielding cows (Ras, 1999). Previous research has shown that anoestrus after AI result to elongation of service period, and consequent economic losses. Several factors affect postpartum anestrous such as nutrition plane, milk yield, body condition score (BCS) at calving, suckling, parity and calving season (Shah et al., 1986; Barile, 2005; El-Wishy, 2007). Another major cause of economic loss in dairy operations is ovarian cysts; cows diagnosed with cysts exhibit extended calving intervals (Bartlett et al., 1986). Ovarian cysts in dairy cows have been reported to be a major cause of economic loss and reproductive dysfunction in dairy operations (Garverick, 1997), and cows diagnosed with cysts often exhibit extended calving intervals (Bartlett et al., 1986). The risk factors for ovarian cysts include milk production volume (Johnson et al., 1966), estrogen content of forages (Barga, 1987), and uterine infections (Bosu and Peter, 1987; Peter et al., 1989).

Table 2: Incidence of parity, number of gynecological disorder and percent of gynecological disorder in dairy cow in jasra block Allahabad.

\begin{tabular}{|c|c|c|}
\hline Parity & No. of disorder & Percent of disorder (\%) \\
\hline 1 & 41 & 21.03 \\
\hline 2 & 55 & 28.21 \\
\hline 3 & 44 & 22.55 \\
\hline 4 & 16 & 8.21 \\
\hline 5 & 18 & 9.23 \\
\hline${\text { Over } 6^{\text {th }}}^{\text {Total }}$ & 21 & 10.77 \\
\hline Tot & 195 & 100 \\
\hline
\end{tabular}

In summary, health cows are critical to maintain optimum gynecological performance. To prevent economic losses, cattle herds should have quality nutrition, yearly pregnancy checks, and disease prevention. Reproductive goals should include maximizing the herd's pregnancy rate, the number of cows bred early in the number of calves born early in the calving thus increasing the producer's ability to make a profit.

\section{References}

[1] Barga U (1987) Incidence, aetiology and treatment of ovarian follicular cysts in a large dairy herd over a tenyear period, J. Vet. Med, Vol.43; pp.-56

[2] Bartlett PC , Kirk JH , Mather EC (1986) Repeated insemination in Michigan Holstein Friesian cattle: Incidence, descriptive epidemiology and estimated economic impact, Theriogenology, Vol.26; pp.309-322

[3] Bartlett PC , Ngategize PK , Kaneene JB , Kirk JH , Anderson SM , Mather EC (1986) Cystic follicular disease in Michigan Holstein-Friesian cattle: Incidence, descriptive epidemiology, ad economic impact, Prev. Vet. Med, Vol.4; pp.-15

[4] Bell AW (1995) Regulation of organic nutrient metabolism during transition from late pregnancy to early lactation, J. Anim. Sci, Vol.73; pp.2804-2819

[5] Bosu WTK, Peter AT (1987) Evidence for a role of intrauterine infections in the pathogenesis of cystic ovaries in postpartum dairy cows , Theriogenology, Vol.28; pp.-725

[6] Butler WR (2000) Nutritional interactions with reproductive performance in dairy cattle, Anim. Reprod. Sci, Vol.60; pp.449-457

[7] Claus R , Karg H , Zwiauer D , von Butler I , Pirchner F , Rattenberger E (1983) Analysis of factors influencing reproductive performance of the dairy cow by progesterone assay in milk-fat, Br. Vet. J., Vol.139; pp.29-37

[8] Dekriuf A (1978) Factors influencing the fertility of a cattle population, J. Reprod. Fert, Vol.54; pp.507-518

[9] de Vries MJ , van der Beek S, Kaal Lansbergen LM , Ouweltjes W , Wilmink JB (1999) Modeling of energy balance in early lactation and the effect of energy deficits in early lactation on first detected estrus postpartum in dairy cows , J. Dairy Sci, Vol.82; pp.1927-1934

[10]El-Wishy AB (2007) The postpartum buffalo. II. Acyclicity and anestrus , Anim. Reprod. Sci, Vol.97; pp.216-236

[11] Ferreira RM , Ayres H , Chiaratti MR , Rodrigues CA, Freitas BG, Meirelles FV, Baruselli PS (2010) Heat stress and embryo production in high-producing dairy cows, Acta. Sci. Vet, Vol.38; pp.277-315

[12] Francos G , Davidson M , Mayer E (1977) The influence of some nutritional factors on the incidence of the repeat breeder syndrome in high producing herds, Theriogenology, Vol.7; pp.105-111

[13] Garverick HA (1997) Ovarian follicular cysts in dairy cows , J. Dairy. Sci, Vol.80; pp.995-1004

[14] Gietema B (2005) Reproduction in Dairy Cattle 1, Agromisa Foundation, pp.-17

[15] Graden AP , Olds D , Mochow CR , Mutter LR (1968) Causes of fertilization failure in repeat breeding cattle , J. Dairy Sci, Vol.51; pp.778-781

[16] Gustafsson H (1985) Characteristics of embryos from repeat breeder and virgin heifers , Theriogenology, Vol.23; pp.487-498

[17] Gustafsson H , Larsson K , Kindahl H , Madej A (1986) Sequentialendocrine changes and behavior during estrus and metoestrus in repeat breeder and virgin estrus and metoestrus heifers, Anim. Reprod. Sci, Vol.10; pp.261273. 
[18] Highshoe, A.P., R.C. Cochran, L.R. Corah, G.H. Kiracofe, D. L. Harmon and R.C. Perry, 1991. Effects of calcium soaps of fatty acids on postpartum reproductive functions in beef cows. J. Anim. Sci., 69: $4097-4103$.

[19] Johnson AD , Legates JE , Ulberg LC (1966) Relationship between follicular cysts and milk production in dairy cattle, J. Dairy Sci, Vol.49; pp.865868

[20] Kesler DJ , Garverick HA (1982) Ovarian cysts in dairy cattle: A review , J. Anim. Sci, Vol.55; pp.1147-1159

[21]Lucy MC (2001) Reproductive loss in high producing dairy cattle: Where will it end, J. Dairy Sci, Vol.84; pp.1277-1293

[22] Lucy MC , Staples CR , Michel FM , Thatcher WW (1991) Energy balance and size and number of ovarian follicles detected by ultrasonography in early postpartum dairy cows , J. Dairy Sci, Vol.74; pp.473482

[23] Mwaanga ES , Janowski T (2000) Anoestrous in dairy cows: Causes, prevalence and clinical forms , Reprod. Dom. Anim, Vol.35; pp.193-200

[24] Opsomer G , de Kruif A (1999) Post-partumer anestrus bei milchkühen-eine ubersicht, Tier rztl. Praxis, Vol.27; pp.30-35

[25]Peter AT , Bosu WTK , DeDecker RJ (1989) Suppression of preovulatory luteinizing hormone surges in heifers after in trauterine infusion of Escherichia coli endotoxin, Am. J. Vet. Res, Vol.50; pp.-368

[26] Rao AVN (1982) Causes and incidence of reproductive disorders among Zebu $\times$ Taurus crossbred cows in Andhra Pradesh, Theriogenology, Vol.17; pp.189-191

[27] Ras A (1999) Badania wplywu zaburzen gospodarki energetycznej na procesy rozrodcze krow mlecznych, Rozprawy I monografie. 18. Wyd ART Olsztyn,

[28] Roberts, S.J., 1971. Veterinary obstetrics and genital diseases. 2nd Edn. CBS publishers and distributors (India) New Delhi., pp 105

[29] Roberts SJ (1971) Veterinary Obstetrics and Genital Diseases, Ann Arbour, pp.-776

[30] Schopper D, Schemer R, Weiler U, Claus R (1993) Einflu $\beta$ der milchleistung auf fruchtbarkeitskriterien der milchkuh post partum: Auswertung von progesteronprofilen, Reprod. Dom. Anim, Vol.28; pp. $225-235$

[31] Shah NH, Willemse AH, Van De Weil DFM (1986) A review of the factors influencing fertility in the postpartum buffalo, Buffalo. J, Vol.2; pp.103-115

[32] Wehrman, M.E., T.H. Welsh, Jr. and G.L. Williams, 1991. Diet induced hyperlipemia in cattle modifies intracellular cholesterol environment, modulates ovarian follicular dynamics and hastens the onset of postpartum luteal activity, Biol. Reprod., 95: 514 - 523. Blood Biochemical profile.... Tamilnadu

[33] Wiltbank MC , Gumen A , Sartori R (2002) Physiological classification of anovulatory comditions in cattle, Theriogenology, Vol.57; pp.21-52

[34] Yusuf M, Nakao T , Ranasinghe RB , Gautam G , Long ST , Yoshida C , Koike K , Hayashi A (2010) Reproductive performance of repeat breeders in dairy herds, Theriogenology, Vol.73; pp.1220-1229 